\title{
PERAN INDONESIA DALAM MEMERANGI TERORISME
}

\author{
Reni Windiani \\ Departemen Hubungan Internasional, Fakultas Ilmu Sosial \& Ilmu Politik, \\ Universitas Diponegoro \\ E-mail: reniwindiani@gmail.com
}

\begin{abstract}
Since the terrorist attacks of September $11^{\text {th }} 2001$ in World Trade Centre (WTC), terrorism becomes a hot issue trough out the world. Almost all states agree to counter terrorism, because terrorism is against humanitarianism, and it has caused losses in economy, politics, and psychology. This research is aimed to describe and analyze Indonesia's multi pronged approach to counter terrorism by using qualitative research method. Based on the data and information provided could be concluded that Indonesia's role in countering terrorism is seen through three aspects, Government has made a legal frame work on anti-terrorism, form an institution which focus on cooperate with ASEAN. Meanwhile in international level, Indonesia has signed an agreement made by the United Nation, and cooperated with other non-ASEAN countries.Based on the result of this research, researcher's suggestions for strengthening Indonesia counter terrorism efforts over the next decade are: intensifying coordination and communication between the central government and local government in the domestic level in order to implement what has been written in the legal framework. In the regional level, ASEAN needs to increase cooperation related to information and defense. Lastly, in the international level, there there are some bilateral and multilateral cooperation that have worked quite well.
\end{abstract}

Key words: terrorism; Indonesia's role; countering terrorism

\begin{abstract}
Abstrak
Sejak serangan teroris 11 September 2001 di World Trade Center (WTC), terorisme menjadi isu yang banyak dibicarakan di belahan dunia manapun. Hampir semua negara setuju untuk melawan terorisme, karena terorisme bertentangan dengan paham kemanusiaan, dan telah menyebabkan kerugian secara ekonomi, politik, dan psikologi. Artikel ini bertujuan untuk mendeskripsikan dan menganalisis dengan menggunakan pendekatan berbagai macam cara Indonesia dalam melawan terorisme dengan menggunakan metode analisa kualitatif. Berdasarkan data dan informasi yang diberikan dapat disimpulkan bahwa peran Indonesia dalam melawan terorisme dilihat melalui beberapa aspek yaitu: Pemerintah telah membuat kerangka kerja hukum tentang anti-terorisme, membentuk lembaga yang fokus pada kerja sama dengan ASEAN. Sementara itu di tingkat internasional, Indonesia telah menandatangani perjanjian yang dibuat oleh PBB, dan bekerja sama dengan negara-negara non-ASEAN lainnya. Berdasarkan hasil analisa ini untuk memperkuat upaya penanggulangan terorisme Indonesia selama periode berikutnya adalah: mengintensifkan koordinasi dan komunikasi antara pemerintah pusat dan pemerintah daerah di tingkat domestik untuk mengimplementasikan apa yang telah ditulis dalam kerangka hukum. Di tingkat regional, ASEAN perlu meningkatkan kerja sama yang terkait dengan informasi dan pertahanan, sedangkan di tingkat internasional ada beberapa kerja sama bilateral dan multilateral yang telah berjalan dengan baik.
\end{abstract}

Kata kunci: terorisme; peran Indonesia; melawan terorisme 


\section{PENDAHULUAN}

Peristiwa pengeboman World Trade Center (WTC) di Amerika Serikat pada 11 September 2001, membawa dampak pada perubahan orientasi politik luar negeri Amerika Serikat. Kekuatan Amerika Serikat dibidang ekonomi, politik, dan militer yang besar, membawa dampak pada berubahnya sikap negara - negara lain di dunia dalam kebijakan domestiknya. Pengaruh Amerika Serikat memang tidak dapat dipungkiri, hal ini dapat kita lihat dari reaksi hampir seluruh negara - negara di dunia ini yang juga berada pada posisi sama dengan Amerika Serikat yaitu "memerangi terorisme", tak terkecuali juga dengan Indonesia.

Terkait dengan Indonesia, kebijakan "memerangi terorisme" ini menjadi realistis mengingat beberapa faktor di lapangan sebagai berikut :

1. Indonesia merupakan salah satu negara yang dianggap memiliki ancaman besar karena Indonesia telah beberapa kali mengalami teror yang dilakukan oleh teroris antara lain: (i) Pada tahun 1998 di Gedung Atrium Senin Jakarta; (ii) Pada tahun1999 di Plaza Hayam Wuruk dan Masjid Istiqlal Jakarta ;(iii) Pada tahun 2000 di Gereja GKPI dan Gereja Katolik Medan serta rumah Dubes Filipina; (iv) Pada tahun 2000 dan 2001 peledakan di beberapa Gereja di malam Natal; (v) Pada tahun 2002 peledakan di Kuta Bali dan di Mc Donald Makasar; (vi) Pada tahun 2003 peledakan di JW Marriot; (vii) Pada tahun 2004 peledakan di Kedubes Australia; (viii) Pada tahun 2005 peledakan bom Bali II; (ix) pada tahun 2009 dua ledakan dahsyat di Hotel JW Marriott dan Ritz-Carlton, Jakarta (www.luarnegeri.kompasiana.com).

2. Indonesia selain merupakan salah satu negara yang dianggap memiliki ancaman besar terorisme karena banyaknya aksi teror yang telah terjadi, juga dikarenakan salah satu kelompok teroris yang paling sering diduga bertanggungjawab terhadap aksi - aksi teror yaitu Jamaah Islamiayah (JI) berbasis di Indonesia. Setelah peristiwa bom Bali 2002 dan ditangkapnya Amrozy, Imam Samudra, dan Muklas, sejumlah analis mengkaitkan terorisme di Indonesia dengan jaringan teroris internasional Al-Qaeda. Pengkaitan dengan jaringan internasional merupakan argumen yang dipercaya oleh masyarakat internasional. Pemerintah Amerika Serikat menyakini keberadaan jaringan Al-Qaeda di Indonesia. Menurut laporan intelejen Singapura dan Malaysia, Al-Qaeda hadir di kawasan Asia Tenggara lewat Jema'ah Islamiah (JI). Kebanyakan pemimpin JI adalah orang Indonesia (Djelantik: 2010:2).

3. Pengebomman sebuah kafe di Bali pada 12 Oktober 2002 dimana korbannya mayoritas orang asing, begitu pula dengan peristiwa pengeboman hotel JW Marriot di Jakarta dimana korbanya juga orang asing, menjadi bukti bahwa teror - teror yang terjadi di Indonesia berskala internasional atau disebut juga sebagai terorisme internasional. 


\section{Jurnal Ilmu Sosial Vol. 16|No. 2| Edisi Juli - Desember 2017 | Hal.135-152}

4. Selain pengeboman - pengebomaman tersebut di atas, aksi teror juga terjadi di Poso, Ambon, dan juga beberapa daerah lain di Indonesia.

Kebijakan Indonesia terkait dengan penanganan terorisme dapat segera dilihat seperti misalnya pembuatan Undang - Undang anti terorisme, menjalin kerjasama ditingkat regional maupun tingkat internasional guna mengatasi terorisme, serta membentuk badan - badan yang menangani terorisme. Upaya - upaya Indonesia dalam memerangi terorisme menarik untuk diteliti mengingat Indonesia sekarang ini masih dalam proses transisi dari pemerintahan totaliter ke pemerintahan yang demokratis. Alberto Abadie (2004), seperti dikutip oleh Djelantik (2010:2) menyatakan bahwa negara yang tengah mengalami masa transisi dari totalitarianisme menuju demokrasi ditandai dengan maraknya aksi - aksi kekerasan termasuk terorisme.

Meskipun banyak pihak menilai Indonesia mengalami ancaman terorisme sejak awal tahu 2000-an, sesunguhnya terror dalam bentuk ancaman terhadap kedaulatan NKRI dan pemerintah yang sah telah dimulai sejak tahun - tahun awal kemerdekaannya. Ancaman tersebut muncul dalam berbagai bentuk pemberontakan dan gerakan - gerakan separatis. Gerakan separatis umumnya melakukan serangan langsung terhadap pemerintah pusat, serta tindakan lainnya seperti sabotase, penculikan dan tindakan - tindakan yang menimbulkan gangguan umum (Surya Bakti. 2014: 10).

Pada era Orde Lama aksi teror mayoritas dilakukan oleh organisasi seperti PRRI/ Permesta, PKI, dan DI/TII. Jika dimasa Orde Lama aksi teror didominasi oleh aksi - aksi separatis, di era Orde Baru aksi teror banyak dilakukan oleh gerakan - gerakan Islam radikal, yang muncul pada pertengahan tahun 1970an hingga awal tahun 1980an. Diantaranya teror yang dilakukan oleh Kelompok Haji Ismail Pranoto yang menamakan dirinya sebagai Komando Jihad, Kelompok Hasan Tiro yang menamakan diri sebagai Front Pembebasan Muslim Indonesia, gerakan kelompok yang dipimpin oleh Abdul Qodir Djaelani yang menyatakan dirinya sebagai penganut Pola Perjuangan Revolusioner Islam, teror yang dilakukan oleh kelompok Warman yang juga menamakan dirinya Komando Jihad, dan teror yang dilakukan oleh kelompok Imran yang menamakan dirinya sebagai Dewan Revolusioner Islam Indonesia. Selain itu aksi terorisme yang terjadi pada era Orde Baru terjadi juga misalnya pada tanggal 28 Maret 1981 yaitu aksi teror atas nama Komando Jihad pimpinan Imran bin Mohammad Zein dengan cara membajak pesawat Garuda 206 dan pada tanggal 21 Januari 1985 yaitu peledakan bom di candi Borobudur (Surya Bakti. 2014: 11-12).

Era Reformasi yang membuka suasana demokratis di Indonesia, ternyata tidak mengurangi aksi - aksi teror. Hal ini dapat dilihat dari peristiwa serangkaian aksi bom di akhir tahun 2000, 2001, 2002, 2003, hingga 2005, serangkaian bom terus mengguncang Indonesia 


\section{Jurnal Ilmu Sosial Vol. 16| No. 2| Edisi Juli - Desember 2017 | Hal.135-152}

dan yang terbesar adalah bom hotel JW Marriot (Agustus 2003), bom di Kedutaan Besar Australia di Jakarta, dan bom Bali 2 Oktober 2005 (Surya Bakti. 2014: 14-15).

Artikel ini membahas masalah peran yang dilakukan oleh Indonesia dalam memerangi terorisme. Peran Indonesia dibahas dalam lingkup internal dan eksternal. Lingkup internal meliputi kebijakan - kebijakan dalam negeri, sedangkang lingkup eksternal menyangkut peran Indonesia dalam memerangi terorisme yang terkait kerjasama dengan negara lain.

\section{METODE PENELITIAN}

Pembahasan dalam artikel ini menggunakan metode kualitatif deskriptif bertujuan untuk memberikan gambaran tentang suatu masyarakat atau kelompok orang tertentu atau gambaran tentang suatu gejala atau hubungan antara dua gejala atau lebih. Masyarakat atau kelompok dalam penelitian ini ialah pemerintah Indonesia, sedangkan yang dimaksud dengan gejala dalam penelitian ini adalah terorisme.

Teknik pengumpulan data dalam penelitian ini menggunakan metode wawancara dan dokumentasi. Wawancara dilakukan dengan pihak Badan Nasional Penanggulangan Terorisme serta informan - informan terkait.

Sumber data dalam artikel ini ini berupa data primer dan data sekunder. Data primer diperoleh melalui wawancara dengan Direktur Keamanan Internasional dan Perlucutan Senjata Kementerian Luar Negeri RI, pihak Badan Nasional PenanggulanganTerorisme (BNPT) serta informan -informan terkait, sedangkan data sekunder diperoleh dari buku buku, laporan resmi pemerintah, dokumen - dokumen, jurnal, koran, majalah, dan internet.

Dalam artikel ini, teknik yang digunakan untuk menguji validitas data dan keabsahan data yang diperoleh dengan cara teknik triangulasi sumber. Menurut Moleong, triangulasi adalah teknik pemeriksaan validitas data yang memanfaatkan sesuatu yang lain di luar data itu untuk keperluan pengecekan atau sebagai pembanding terhadap data itu. Denzin membedakan empat macam triangulasi sebagai teknik pemeriksaan keabsahan datanya yang memanfaatkan sumber, metode, penyidik, dan dengan teori (Moleong Lexy J,1994:178).

Analisis data dalam artiel ini dilakukan melalui :

1. Reduksi data, yaitu dengan merangkum, memilah-milah data pokok, kemudian memfokuskan dan menyusun data secara sistematik.

2. Display data, yaitu dengan menyajikan data tertentu dalam bentuk matriks, grafik, charts, atau network bila diperlukan.

3. Verifikasi data, yaitu dengan mencari pola, tema hubungan serta persamaan - persamaan, perbandingan dan kemudian membuat kesimpulan. 


\section{Jurnal Ilmu Sosial Vol. 16|No. 2| Edisi Juli - Desember 2017 | Hal.135-152}

\section{HASIL DAN PEMBAHASAN}

Hasil penelitian ini memperlihatkan bahwa Indonesia memiliki peran yang cukup penting dalam kaitannya dengan penanggulangan terorisme. Hal ini dapat dilihat dari upaya upaya yang telah dilakukan Indonesia baik upaya secara internal maupun upaya secara eksternal.

Terorisme telah membawa dampak negatif dalam kehidupan pribadi korban beserta keluarganya dan juga membawa dampak negatif bagi bangsa dan negara. Bagi keluarga korban kebiadaban teroris membawa dampak psikologis yang berat, rasa kehilangan orang orang tercinta merupakan beban psikologis yang sulit dihadapi. Bagi Negara aksi - aksi kekerasan yang dilakukan oleh teroris berakibat buruk pada citra keamanan dan kenyamanan negara tersebut. Oleh karena itu pemerintah harus serius dalam menangulangi terorisme.

Indonesia secara serius sudah melakukan upaya - upaya penanggulangan terorisme, upaya ini dapat digolongkan ke dalam dua cakupan yaitu internal dan eksternal. Upaya internal adalah upaya - upaya penanggulangan terorisme yang dilakukan oleh pemerintah Indonesia tanpa melibatkan negara lain, sedangkan upaya eksternal adalah upaya penanggulangan terorisme yang dilakukan dengan negara lain baik dalam lingkup regional maupun lingkup internasional.

Secara internal upaya yang dilakukan oleh Indonesia guna menanggulangi terorisme adalah sebagai berikut :

\section{Penegakan Hukum.}

Salah satu prinsip pokok strategi penanggulangan terorisme Indonesia menurut Ketua BNPT adalah bahwa Pemerintah Indonesia memperlakukan aksi terorisme sebagai tindakan kriminal, sehingga yang digunakan adalah pendekatan hukum. Penyelenggaraan penegakkan hukum terhadap tindak pidana terorisme diatur oleh UU No. 15 tahun 2003 yang menetapkan Perpu No. 1 tahun 2002 tentang Pemberantasan Tindak Pidana Terorisme sebagai Undang - Undang. Kemudian dibuat UU No. 8 Tahun 2010 tentang Pencegahan dan Pemberantasan Tindak Pidana Pencucian Uang dan No. 9 Tahun 2013 tentang Pencegahan dan Pemberantasan Tindak Pidana Pendanaan Terorisme. Secara umum, strategi penegakkan hukum ini dapat dikatakan masih menghadapi berbagai tantangan. Penegakan hukum terhadap sistem kejahatan terorisme dipandang masih lemah. Dari segi payung hukum, institusi keamanan nasional mengalami masalah karena keberadaan UU No.15 tahun 2003 tentang Pemberantasan Tindak Pidana Terorisme belum cukup memayungi operasi pencegahan dalam bentuk operasi intelijen dan tindakan proaktif di awal. Konsepsi Strategi dan Kebijakan Penanggulangan Terorisme di Indonesia (www.academia.edu). 
2. Pembentukan Badan Nasional Penanggulangan Teroris (BNPT).

BNPT dibentuk melalui Peraturan Presiden Nomor 46 tahun 2010, yang kemudian diubah dengan Peraturan Presiden Nomor 12 tahun 2012. Pembentukan BNPT merupakan Kebijakan Nasional Penanggulangan Terorisme di Indonesia. Badan ini merupakan pengembangan dari Desk Koordinasi Pemberantasan Terorisme (DKPT) yang dibuat pada tahun 2002. BNPT juga dibentuk merupakan sebuah regulasi sebagai elaborasi UU No.34/2004 tentang TNI dan UU No.2/2002 tentang Polri, untuk mengatur ketentuan lebih rinci tentang "Rule of Engagement" (aturan pelibatan ) TNI, terkait tugas operasi militer selain perang, termasuk aturan pelibatan TNI dalam mengatasi terorisme dan tugas perbantuan TNI terhadap Polri (Agus, 2014:74).

3. Pelibatan TNI dan Polri.

UU No 34 tahun 2004 telah memberikan payung hukum agar TNI juga terlibat dalam mengatasi aksi terorisme. Yang seharusnya dilakukan prajurit TNI, bukan bagaimana penanganan setelah bom meledak, mencari siapa pelakunya, akan tetapi lebih pada upaya preventif. Memberikan bantuan kepada kepolisian dengan koridor fungsi dan tugasnya secara efektif. Merujuk pada Undang Undang No. 34 tahun 2004 tentang TNI di Pasal 7 ayat 1 sangat jelas dinyatakan, bahwa tugas pokok TNI adalah menegakkan kedaulatan negara, mempertahankan keutuhan wilayah NKRI yang berdasarkan Pancasila dan UUD 1945, serta melindungi segenap bangsa dan seluruh tumpah darah Indonesia dari ancaman dan gangguan terhadap keutuhan bangsa dan negara. Sebagai penegas, di ayat 2 pasal tersebut dinyatakan, tugas pokok sebagaimana dimaksud yakni dengan melakukan operasi militer untuk perang dan operasi militer selain perang. Operasi militer selain perang, diperuntukkan antara lain sebagai upaya untuk mengatasi gerakan separatis bersenjata, pemberontakan bersenjata, aksi terorisme serta mengamankan wilayah perbatasan. Dari pasal ini saja, mengisyaratkan bahwa tidak ada alasan bagi TNI untuk tidak terlibat dalam menanggulangi terorisme yang nyata-nyata tidak sekedar menghancurkan citra kehormatan bangsa di mata internasional, tetapi sudah menghancurkan sendi-sendi kemanusiaan (www.tni.mil.id).

4. Deradikalisasi.

Deradikalisasi adalah bagian dari strategi kontra terorisme, deradikalisasi dipahami sebagai cara merubah idiologi kelompok teroris secara drastis. Deradikalisasi ditujukan untuk mengubah seseorang yang semula radikal menjadi tidak lagi radikal, termasuk diantaranya adalah menjauhkan mereka dari kelompok radikal tempat mereka bernaung. Deradikalisasi terorisme diwujudkan dengan program reorientasi motivasi, reedukasi, 
resosialisasi, serta mengupayakan kesejahteraan social dan kesetaraan dengan masyarakat lain bagi mereka yang terlibat terorisme maupun bagi simpatisan (Agus, 2014:174).

Upaya - upaya internal yang dilakukan Indonesia dalam menangani terorisme sebagaimana tersebut di atas, menggunakan prinsip hard power dan soft power. Hard power diterapkan melalui penegasan keterlibatan TNI dan Polri yang dituangkan dalam UU Nomor 34 tahun 2004, sedangkan prinsip soft power termanifestasikan dalam program deradikalisasi.

Selain melakukan upaya internal, Indonesia juga melakukan upaya eksternal dalam penanggulangan terorisme. Upaya eksternal ini dilakukan secara bilateral dan juga secara multilateral. Usaha yang dilakukan oleh pemerintah Indonesia dalam menanggulangi terorisme dalam lingkup regional adalah melalui forum ASEAN Chiefs of National Police.Polri juga menjalin kerjasama regional dan internasional dalam berbagai forum ASEAN, seperti : ARF ( ASEAN Regional Forum), dan AMMTC ( ASEANMinisterial Meeting on Transnational Crime ). Berbagai forum lain, seperti ASEAN Chiefs of Army Multilateral Meeting, Asia Pacific Economic Cooperation ( APEC), dan Asia-Europe Meeting ( ASEM ), secara rutin juga mengagendakan ancaman terorisme dan cara penanggulangannya (repository.unand.ac.id).

Pendirian Jakarta Center for Law Enforcement Cooperation (JCLEC) merupakan bentuk kerjasama bilateral antara Indonesia dengan Australia yang dipicu dengan peledakan bom Bali. JCLEC diresmikan oleh Presiden Megawati pada 3 Juli 2004, meskipun berupa kerjasama bilateral JCLEC yang memfokuskan pada pelatihan penegak hukum dalam penanggulangan terorisme, peserta pelatihan meliputi banyak negara. Sampai di usianya yang ke 10 JCLEC telah berkontribusi melatih penegak hukum dari 70 negara. (Wawancara dengan bapak Andy Rachmianto, Direktur Keamanan Internasional dan Perlucutan Senjata Kementerian Luar Negeri RI). Meeting ( ASEM ), secara rutin juga mengagendakan ancaman terorisme dan cara penanggulangannya (repository.unand.ac.id).

Pendirian Jakarta Center for Law Enforcement Cooperation (JCLEC) merupakan bentuk kerjasama bilateral antara Indonesia dengan Australia yang dipicu dengan peledakan bom Bali. JCLEC diresmikan oleh Presiden Megawati pada 3 Juli 2004, meskipun berupa kerjasama bilateral JCLEC yang memfokuskan pada pelatihan penegak hukum dalam penanggulangan terorisme, peserta pelatihan meliputi banyak negara. Sampai di usianya yang ke 10 JCLEC telah berkontribusi melatih penegak hukum dari 70 negara (Wawancara dengan bapak Andy Rachmianto, Direktur Keamanan Internasional dan Perlucutan Senjata Kementerian Luar Negeri RI). 


\section{Jurnal Ilmu Sosial Vol. 16|No. 2| Edisi Juli - Desember 2017 | Hal.135-152}

Indonesia juga tercatat sebagai Anggota Asia -Pacific Group on Money Laundering , menandatangani $\mathrm{MoU}$ dengan lebih dari 46 Financial IntelligenceUnit, menandatangani Bilateral Joint Working Group on Counter-Terrorism (khususnya dengan BNPT), juga dilakukan Intelligence sharing, capacity building,technical cooperation.

Upaya penanggulangan terorisme yang dilakukan Indonesia pada Tingkat Multilateral yaitu : penanggulangan terorisme melalui UNODC, UN Counter-Terrorism Executive Directorate, UN Counter-Terrorism Implementation Task Force, UN Global CounterTerrorism Strategy. Indonesia merupakan salah satu advisory board dari UN Counter-Terrorism Center, Indonesia juga mendukung pembahasan pembentukan "Comprehensive Convention on Counter Terrorism", Indonesia sebagai Co-chair dari Detention and Reintegration Working Group dari Global Counter TerrorismForum (GCTF), dan Indonesia juga mendukung Resolusi DK PBB 2178 (2014) tentang foreign terrorist fighters. (Kuliah Umum :Keamanan Internasional dan Perlucutan Senjata : Melacak Kontribusi Indonesia, Andy Rachmianto, Direktur Keamanan Internasional dan Perlucutan Senjata Kementerian Luar Negeri RI, Undip 8 Oktober 2014). Upaya eksternal yang dilakukan Indonesia dalam menangulangi terorisme ternyata cukup banyak sebagaimana tampak pada perjanjian dan dukungan Indonesia terhadap kerjasama penangugulangan terorisme baik secara bilateral maupun multilateral.

Adapun Hasil-hasil yang telah dicapai dalam pencegahan dan penanggulangan terorisme adalah tertangkapnya pelaku terorisme, termasuk dua tokoh utamanya, Dr.Azahari dan Abu Dujana pada tahun 2005 dan 2007. Selanjutnya, pada tahun 2006 Polri berhasil melakukan penggerebekan tempat persembunyian anak buah Noordin M. Top di Wonosobo, yaitu Jabir, Abdul Hadi (kepercayaan dr. Azhari), Solehudin dan Mustarifin. Pada tahun 2008 berbagai operasi yang dilakukan oleh densus 88 atau Bareskrim Polri berhasil menangkap 28 orang pelaku terorisme di Indonesia. Tahun 2009 Polri berhasil menangkap beberapa tersangka kelompok teroris di Palembang, Lampung dan Jawa Tengah yang diperkirakan terlibat dalam rencana aksi teroris di dalam negeri dan luar negeri. Tertangkapnya sebagian anggota jaringan teroris tersebut yang diperkirakan merupakan kelompok Noordin M. Top, menandakan bahwa tugas pemberantasan terorisme belum tuntas dan ke depan tetap memerlukan kewaspadaan yang tinggi. Terbunuhnya seorang teroris yang diduga sebagai Nurdin M.Top dalam sebuah penyergapan di desa Beji Temanggung, merupakan kunci keberhasilan aparat keamanan dalam pengungkapan peledakan Hotel Ritz-Carlton dan J.W. Marriot tanggal 17 Juli 2009 (www.bappenas.go.id). 


\section{Jurnal Ilmu Sosial Vol. 16|№. 2| Edisi Juli - Desember $2017 \mid$ Hal.135-152}

Hasil dari upaya - upaya yang dilakukan Indonesia dalam menangani terorisme yang dipublikasikan masih menunjukkan keberhasilan dari sisi penanggulangan secara hard power. Telah tercapai konsensus di tingkat nasional bahwa penggunaan hard power atau langkahlangkah yang represif saja tidak cukup untuk menanggulangi terorisme di Indonesia yang dipercaya berakar pada permasalahan-permasalahan lain yang lebih luas seperti kondisikondisi deprivasi (kemiskinan, kurangnya pendidikan dan layanan dasar, dan sebagainya) dan ideologi yang radikal yang memanfaatkan kondisi-kondisi tersebut (www.academia.edu). Keberhasilan penanggulangan terorisme dari sisi soft power lebih bisa dirasakan secara psikologis yaitu timbulnya rasa aman di masyarakat baik di tingkat lokal maupun di tingkat internasional dalam tata hubungan internasional yang akan berdampak pula pada kondisi sosial politik dan ekonomi negara bangsa.

Hasil penelitian juga mengungkap beberapa kendala penanggulangan terorisme, antara lain :

1. Dari perspektif militer melihat bahwa saat ini belum ada payung hukum yang kuat bagi kegiatan intelijen untuk mendukung upaya pencegahan dan penanggulangan terorisme. Sulitnya menyusun payung hukum tersebut karena adanya pemahaman sempit sementara kalangan umat beragama, bahwa perang melawan terorisme dianggap memerangi Islam.

2. Kondisi masyarakat Indonesia yang menghadapi persoalan ekonomi dan sosial, dimana jumlahnya cukup banyak sangat mudah dipengaruhi atau direkrut menjadi anggota kelompok teroris.

3. Kelompok teroris di Indonesia disinyalir memiliki sumber pendanaan kuat, struktur organisasi yang jelas, dan pola perekrutan anggota atau jaringan yang baru.

4. Kemajuan teknologi global, seperti internet dan telepon seluler, mempermudah berkomunikasi dengan kelompoknya. Di samping itu, para teroris juga mempunyai kemudahan untuk melakukan perjalanan dan transportasi lintas batas negara sehingga sangat sulit untuk memutuskan rantai jaringan terorisme global .

5. Dalam lingkup eksternal masih ada beberapa hambatan dalam pelaksanaan kerjasama antar negara dalam penanggulangan terorisme. Hal ini terkait dengan kepentingan nasional masing - masing negara bangsa. 
Perserikatan Bangsa - Bangsa mendefinisikan terorisme sebagai : (Winarno, 2011:170) :

terrorism is an anxiety-inspiring method of repeated violent action, employed by(semi) clandestine individual, group, or state actors, for idiosyncratic, criminal or political reason, whereby - in contrast to assassination- the direct targets of attacks are not the main targets. The immediate human victims of violence are generally chosen randomly (targets or opportunity) or selectively (representative or symbolic targets) from a target population, and serve as message generators. Threat - and violence - based communication processes between terrorist (organization), (imperiled) victims, and main targets are used to manipulate the main target (audience(s)), turning it into a target of terror, a target of demands, or a target of attention, depending on whether intimidation, coercion, or propaganda is primarly sought.

Viotti dan Kauppi dalam (Winarno, 2011: 171) mendefinisikan teroisme sebagai : "Terrorism, as politically motivated violence, aims at achieving a demoralizing effect on publics and governments”. Robertson dalam (Winarno, 2011:171) mengemukakan ada tiga ciri utama terorisme yaitu : penggunaan kekerasan, targetnya adalah orang - orang yang tidak bersalah, dan mereka berusaha untuk menarik perhatian atas tuntutan mereka. Sedangkan T.P.Thornton dalam Terror as a Weapon of Political Agitation (1964) mengkaitkan terorisme dengan politik dan kekuasaan sebagaimana terlihat dalam definisi terorisme yang dikemukannya sebagai penggunaan teror sebagai tindakan simbolis yang dirancang untuk mempengaruhi kebijakan dan tingkah laku politik dengan cara-cara ekstra normal, khususnya dengan penggunaan kekerasan dan ancaman kekerasan. Terorisme dapat dibedakan menjadi dua kategori, yaitu enforcement terror yang dijalankan penguasa untuk menindas tantangan terhadap kekuasaan mereka, dan agitational terror, yakni teror yang dilakukan menggangu tatanan yang mapan untuk kemudian menguasai tatanan politik tertentu (www.eramuslim.com). 
Sedangkan dalam penjelasan atas Peraturan Pemerintah Pengganti Undang -Undang Republik Indonesia Nomor 2 Tahun 2002 tentang Pemberlakuan Peraturan Pemerintah Pengganti Undang-Undang Republik Indonesia Nomor 1 Tahun 2002 tentang Pemberantasan Tindak Pidana Terorisme, dinyatakan bahwa: "Terorisme merupakan kejahatan terhadap kemanusiaan dan peradaban serta merupakan salah satu ancaman serius terhadap kedaulatan setiap negara, karena terorisme sudah merupakan kejahatan yang bersifat internasional yang menimbulkan bahaya terhadap keamanan, perdamaian dunia serta merugikan kesejahteraan masyarakat sehingga perlu dilakukan pemberantasan secara berencana dan berkesinambungan sehingga hak asasi orang banyak dapat dilindungi dan dijunjung tinggi". Dari beberapa definisi tersebut di atas, dapat ditarik benang merah tentang terorisme yaitu bahwa terorisme adalah tindakan kejahatan dengan menggunakan kekerasan, yang menimbulkan rasa takut serta berdampak negatif terhadap aspek politik, ekonomi, dan sosial.

Masyarakat perlu mengetahui bahwa terorisme bukanlah hal baru dalam kehidupan sosial maupun politik. Menurut sejarah meski istilah Teror dan Terorisme baru mulai populer abad ke-18, namun fenomena yang ditujukannya bukanlah baru. Menurut Grant Wardlaw dalam buku Political Terrorism (1982), manifestasi Terorisme sistematis muncul sebelum Revolusi Perancis, tetapi baru mencolok sejak paruh kedua abad ke-19. Perkembangannya bermula dalam bentuk fanatisme aliran kepercayaan yang kemudian berubah menjadi pembunuhan, baik yang dilakukan secara perorangan maupun oleh suatu kelompok terhadap penguasa yang dianggap sebagai tiran. Pembunuhan terhadap individu ini sudah dapat dikatakan sebagai bentuk murni dari Terorisme dengan mengacu pada sejarah Terorisme modern.

Kata Terorisme berasal dari Bahasa Perancis le terreur yang semula dipergunakan untuk menyebut tindakan pemerintah hasil Revolusi Perancis yang mempergunakan kekerasan secara brutal dan berlebihan dengan cara memenggal 40.000 orang yang dituduh melakukan kegiatan anti pemerintah. Selanjutnya kata Terorisme dipergunakan untuk menyebut gerakan kekerasan anti pemerintah di Rusia. Dengan demikian kata Terorisme sejak awal dipergunakan untuk menyebut tindakan kekerasan oleh pemerintah maupun kegiatan yang anti pemerintah (eprints.undip.ac.id). 
Terorisme muncul pada akhir abad 19 dan menjelang terjadinya Perang Dunia-I, terjadi hampir di seluruh belahan dunia. Pada pertengahan abad ke-19, Terorisme mulai banyak dilakukan di Eropa Barat, Rusia dan Amerika. Mereka percaya bahwa Terorisme adalah cara yang paling efektif untuk melakukan revolusi politik maupun sosial, dengan cara membunuh orang-orang yang berpengaruh. Adapun bentuk pertama Terorisme, terjadi sebelum Perang Dunia II, Terorisme dilakukan dengan cara pembunuhan politik terhadap pejabat pemerintah. Bentuk kedua Terorisme dimulai di Aljazair di tahun 50an, dilakukan oleh FLN yang mempopulerkan "serangan yang bersifat acak" terhadap masyarakat sipil yang tidak berdosa. Hal ini dilakukan untuk melawan apa yang disebut sebagai Terorisme negara oleh Algerian Nationalist. Pembunuhan dilakukan dengan tujuan untuk mendapatkan keadilan. Bentuk ketiga Terorisme muncul pada tahun 60an dan terkenal dengan istilah "Terorisme Media", berupa serangan acak terhadap siapa saja untuk tujuan publisitas (www.eramuslim.com).

Fenomena Terorisme meningkat sejak permulaan dasawarsa 1970-an. Terorisme dan Teror telah berkembang dalam sengketa ideologi, fanatisme agama, perjuangan kemerdekaan, pemberontakan, gerilya, bahkan juga oleh pemerintah sebagai cara dan sarana menegakkan kekuasaannya. Sebagai bagian dari fenomena sosial, terorisme jelas berkembang seiring dengan perkembangan peradaban manusia. Cara-cara yang digunakan untuk melakukan kekerasan dan ketakutan juga semakin canggih seiring dengan kemajuan teknologi modern. Proses globalisasi dan budaya massa menjadi lahan subur perkembangan terorisme. Kemudahan menciptakan ketakutan dengan teknologi tinggi dan liputan media yang luas membuat jaringan dan tindakan teror semakin mudah mencapai tujuan. Saat ini, motif terorisme lebih sering dikaitkan dengan dimensi moral yang luas seperti nilai, ideologi, agama, ketidakadilan tatanan dan struktur sosial maupun konstelasi dunia (www.eramuslim.com).

Dalam perjalanan sejarahnya ternyata terorisme tidak mengalami kemunduran baik dari sisi teknologi yang digunakan maupun juga dari sisi intensitas kejadiannya. Peristiwa Tragedi 11 September 2011 di Amerika Serikat, telah memunculkan paradigma baru mengenai terorisme. Serangan terhadap gedung World Trade Centre di Amerika Serikat melahirkan kebijakan 'Gerakan Koalisi Dunia', gerakan di bawah komando Amerika Serikat ini menerapkan berbagai cara berkekuatan nasional maupun internasional dalam komandonya : diplomasi, tekanan hukum, intelejen, pemeriksaan keuangan, aksi militer, dan bantuan pangan. Di tingkat diplomasi, sudah ditandatangani resolusi Dewan Keamanan PBB yang mewajibkan ke- 189 anggotanya,termasuk Indonesia, untuk mengakhiri semua aksi terorisme di dalam negerinya dengan cara menyetop sumber-sumber dana serta membawa pelaku teror untuk diadili. (repository.unand.ac.id). 
Tragedi 11 September 2011 di Amerika Serikat melahirkan konsep atau definisi baru terorisme seperti dalam USA Patriot Act 2001 yaitu terorisme adalah "suatu aksi seperti pembajakan dan perusakan sarana transportasi yang digunakan untuk merusak terhadap sarana prasarana baik dengan api maupun senjata biologi sebagai senjatanya, serta penyerangan terhadap orang - orang yang dilindungi seperti pemerintah baik hanya ancaman, konspirasi maupun percobaan aksi. (USA Patriot Act 2001). The European Union Council Framework Decision on Combating Terrorism mendefinisikan terorisme sebagai: “... dengan serius mengintimidasi sebuah populasi, atau memaksa pemerintah atau organisasi internasional untuk berbuat atau tidak berbuat dalam suatu aksi, perjanjian, atau dengan serius menggoyahkan atau menyerang fundamental politik, konstitusi, ekonomi atau struktur sosial suatu negara atau organisasi internasional". Tindakan yang dianggap sebagai serangan teroris :

A. Menyerang nyawa seseorang yang dapat menyebabkan kematian;

B. Menyerang integritas sesorang secara fisik;

C. Menculik atau menyandera;

D. Menyebabkan kerusakan luas pada pemerintah atau fasilitas umum, sistem transportasi, sarana infrastruktur, termasuk sarana informasi, yang diletakkan di landasan benua, sarana publik atau pribadi yang dapat membahayakan nyawa manusia atau kerugian ekonomi yang besar;

E. Perampasan pesawat, kapal atau transportasi public maupun transportasi barang;

F. Manufaktur, memiliki, mendapatkan, mengangkut, menyediakan atau menggunakan senjata, peledak atau nuklir, senjata biologi atau kimia, termasuk seperti meneliti dan mengembangkan senjata biologi dan kimia;

G. Melepaskan zat kimia, atau membuat api, banjir atau ledakan yang dimaksudkan untuk membahayakan nyawa manusia;

H. Mencampur atau mengganggu persediaan minuman, listrik atau sumber daya alam yang dimaksudkan untuk membahayakan nyawa manusia;

I. Mengancam melakukan segala aksi yang ditulis dalam (a) hingga (h). (Dumitriu, Eugenia.2004. The E.U.'s Definition of Terrorism: The Council Frame-work Decision on Combating Terrorism (www.germanlawjournal.com).

Definisi terorisme sebagaimana tersebut di atas lebih spesifik dan rinci, di samping itu perubahan definisi terorisme menggambarkan bahwa sejarah terorisme akan terus berubah sesuai dengan jaman. 


\section{Kerjasama Internasional}

Terorisme telah menyebar ke seluruh dunia, aktor serta aksi yang mereka lakukan telah menembus batas - batas antar negara, oleh karena itu terorisme dapat dikategorikan sebagai kejahatan transnasional. Untuk itu penanganannya juga harus lintas batas negara. Terorisme telah dinyatakan sebagai ancaman yang serius serta membahayakan ketertiban dan keamanan dunia, hal ini dapat kita lihat dari sikap Perserikatan Bangsa - Bangsa (PBB) yang pada tahun 1995 yang mengidentifikasikan 18 jenis kejahatan transnasional yang salah satu di dalamnya adalah terorisme. Oleh karenanya kemudian masalah terorisme dijadikan agenda tetap dalam hubungan internasional baik bersifat bilateral maupun multilateral. Pemberantasan terorisme mutlak memerlukan kerjasama internasional dan tidak satupun Negara di dunia yang dapat bebas dan terhindar dari ancaman terorisme.

Hubungan Internasional di abad 20 makin bertambah kompleks, tidak hanya karena makin banyaknya aktor yang terlibat tetapi juga dikarenakan makin banyaknya permasalahan yang timbul. Realitas ini menciptakan saling ketergantungan antar negara yang semakin nyata, dimana tidak ada satupun negara yang bisa mengatasi permasalahan tanpa kerjasama dengan negara lain.

Kerjasama internasional yang disuarakan oleh kaum Neoliberal menjadi relevan. Ada empat tipe Neoliberalisme; (a) tipe pertama yaitu liberalisme sosiologis yaitu suatu aliran pemikiran neoliberal yang menekankan dampak dari perluasan aktivitas -aktivitas lintas batas baik di bidang perdagangan, komunikasi, pertukaran budaya, dan hubungan transaksi lintas batas lainnya yang lebih tinggi; (b) tipe ke dua dikenal sebagai liberalisme interdependensi, tokohnya Robert Keohane dan Joseph Nye yang mengemukakan konsep Interdependensi Kompleks (Complex Interdependence), yaitu ada banyak bentuk hubungan antar masyarakat sebagai tambahan pada hubungan politik pemerintah termasuk kaitan transnasional di perusahaan - perusahaan bisnis, selain itu adanya ketiadaan hirarki diantara isu - isu; (c) tipe ke tiga adalah liberalisme institusional yaitu ketika terdapat derajat interdependensi yang tinggi, negara - negara akan sering membentuk institusi - institusi internasional untuk menghadapi masalah - masalah bersama. Institusi - institusi memajukan kerjasama lintas batas - batas internasional dengan menyediakan informasi dan dengan mengurangi biaya; (d) tipe ke empat yaitu liberalisme republikan yang menekankan pada peran demokrasi liberal dalam perdamaian (Jacson \& Sorensen : 2005 :62 - 66).

Dilihat dari rangkaian kejadian aksi - aksi teror sebagaimana tersebut di atas, terlihat bahwa Indonesia tidak pernah lepas dari ancaman teror, baik yang sifatnya terorisme domestik maupun terorisme internasional. Data - data tersebut di atas, memperlihatkan bahwa upaya - upaya yang dilakukan oleh Indonesia guna memerangi terorisme sangat 
penting. Dari upaya - upaya yang sudah dilakukan baik secara internal maupun upaya secara eksternal, hal penting yang semestinya dilakukan oleh Indonesia adalah memaksimalkan kinerja pemerintahan yang diselaraskan antara pemerintah pusat dan pemerintah daerah, sehingga cita - cita masyarakat adil dan makmur dapat tercapai.

\section{KESIMPULAN}

Kesimpulan dari artikel ini adalah bahwa Indonesia telah banyak melakukan upaya upaya dalam menangulangi terorisme. Upaya tersebut dilakukan dalam lingkup internal dan eksternal. Upaya penanggulangan terorisme dalam lingkup internal menggunakan metode hard power dan metode soft power. Upaya penanggulangan secara internal dilakukan dengan penegakan hukum, pembentukan BNPT, pelibatan TNI dan Polri.

Adapun dikarenakan terorisme merupakan bentuk kejahatan yang mengancam keamanan dan ketertiban tidak hanya di Indonesia tapi juga dunia, maka diperlukan kerjasama baik bilateral maupun multilateral. Untuk itu Indonesia juga telah menjalin kerjasama penanggulangan terorisme di tingkat regional dan internasional. Bentuk kerjasama ini merupakan upaya penanggulangan terorisme dari aspek eksternal.

Upaya - upaya penanggulangan terorisme yang dilakukan Indonesia menunjukkan bahwa peran Indonesia cukup besar, hal ini diperkuat dengan hasil - hasil penangkapan pelaku teroris dan pengungkapan kasus teroris di Indonesia. Namun demikian masih ada beberapa kendala yang dihadapi Indonesia dalam upaya menanggulangi terorisme baik dalam skala internal maupun dalam skala eksternal.

\section{SARAN}

1. Pemerintah hendaknya lebih banyak melibatkan masyarakat dalam upaya penanggulangan terorisme.

2. Masyarakat diberi pemahaman mengenai bahaya dan dampak - dampak terorisme.

3. Pemerintah hendaknya meningkatkan kesejahteraan masyarakat untuk mengurangi kemiskinan dan pengangguran.

4. Pemerintah pusat hendaknya menjalin koordinasi yang baik dengan pemerintah daerah, sehingga semua kebijakan terkait dengan penangulangan terorisme dapat diimplementasikan sesuai sasaran kebijakan. 


\section{Daftar Pustaka}

Arikunto, Suharsini. 1998. Prosedur Penelitian:Suatu Pendekatan Praktek. Rineka Cipta, Jakarta.

Bakry, Suryadi Umar. 1999. Pengantar Hubungan Internasional, Jayabaya University Press, Jakarta.

Columbis A. Theodore dan Wolfe H. James. 1978. Introduction to International Relations, Power and Justice, Prestice-Hall, Inc. New Jersey.

Djari, L. 2013. Marthen. Terorisme dan TNI, CMB Press, Jakarta.

Djelantik,Sukawarsini. 2010. Terorisme, Tinjauan Psiko-Politis, Peran Media, Kemiskinan, dam Keamanan Nasional, Pustaka Obor Indonesia, Jakarta.

Frankel, J. 1980. Hubungan Internasional, Sungguh Bersaudara, Jakarta.

Golose, R. Petrus. 2009. Deradikalisasi Terorisme, Humanis, Soul Approach, dan menyentuh Akar Rumput, CV.Aksara Simpati, Jakarta.

Holsti, K.J. 1989. Politik Internasional: Kerangka untuk Analisis, Erlangga, Jakarta.

Jackson, Robert \& Sorensen, Georg. 2005. Pengantar Studi Hubungan Internasional, Pustaka Pelajar, Yogyakarta.

Moleong, Lexy J. 2007. Metodologi Penelitian Kualitatif, PT. Remaja Rosadakarya, Bandung.

Mubah, A Safril. 2012. Teroris versus Globalisasi, PT. Revka Petra Media, Surabaya.

Nainggolan, P. Poltak (ed.), 2002. Terorisme dan Tata Dunia Baru, CV. Tiga Putra Utama, Jakarta.

Rachmianto, Andy. Direktur Keamanan Internasional dan Perlucutan Senjata Kementerian Luar Negeri RI. Semarang, 8 Oktober 2014, jam 09.15 WIB

Soeprapto, R. 1997. Hubungan Internasional, PT. RajaGrafindo Persada, Jakarta.

Surya Bakti, Agus. 2014. Darurat Terorisme, Kebijakan Pencegahan, Perlindungan dan Deradikalisasi, Daulat Press, Jakarta.

Winarno, Budi. 2002. Isu - Isu Global Kontemporer, CAPS, Yogyakarta.

Undang - undang Nomor 37 tahun 1999 tentang Hubungan Luar Negeri.

Undang -Undang No. 15 tahun 2003 yang menetapkan Perpu No. 1 tahun 2002 tentang Pemberantasan Tindak Pidana Terorisme.

Undang - Undang No. 8 Tahun 2010 tentang Pencegahan dan Pemberantasan Tindak Pidana Pencucian Uang. Undang - undang No. 9 Tahun 2013 tentang Pencegahan dan Pemberantasan Tindak Pidana Pendanaan Terorisme. 
Kompas, Jakarta, 3 April 2014.

Kompas, Jakarta, 4 April 2014.

Wikipedia, the free encyclopedia, diakses Rabu 5 Juni 2014 jam 09.00 WIB.

http://www.scribd.com/doc/75973787/4/F-1-Definisi-Peran, diakses Rabu 5 Juni 2014 jam 8.00 WIB.

http://pustaka.pu.go.id/new/artikel-detail.asp?id=297 diakses Selasa 4 Juni 2014 jam 14.05. WIB.

http://luar-negeri.kompasiana.com/2011/01/14/peran-amerika-serikat-dalam-memerangi-

terorisme-di-indonesia-334759.html, diakses Sabtu 27 September 2014 jam 19.49

WIB

https://www.academia.edu/6067495/

Strategi_Pencegahan_dan_Penanggulangan_Terorisme_di_Indonesia, diakses Sabtu,

27 September 2014 jam 19.00WIB

http://www.tni.mil.id/view-3835-keterlibatan-tni-dalam-memerangi-terorisme.html ,diakses

Sabtu 27 September 2014 jam 13.40 WIB

http://repository.unand.ac.id/17447/1/skripsi_siti.pdf, diakses Selasa 14 Oktober 2014 jam

$11.43 \mathrm{WIB}$

http://www.bappenas.go.id/files/3513/4986/1937/bab-6 20091007094529 2158_ 7.pdf,

diakses Sabtu 27 September 2014 jam 13.56 WIB

https://www.academia.edu/6067495/

Strategi_Pencegahan_dan_Penanggulangan_Terorisme_di_Indonesia, diakses Sabtu,

27 September 2014 jam 19.00WIB

http://www.eramuslim.com/berita/analisa/teror-akar-sejarah-dan-

perkembangannya.htm\#.VChyyhYgnIU, diakses Senin, 29 September 2014 jam 3.45

WIB. 
http://eprints.undip.ac.id/38355/3/BAB_2.pdf, diakses Senin, 28 September 2014 jam 3.30 WIB

http://www.eramuslim.com/berita/analisa/teror-akar-sejarah-danperkembangannya.htm\#.VChyyhYgnIU, diakses Senin, 29 September 2014 jam 3.45 WIB.

http://www.eramuslim.com/berita/analisa/teror-akar-sejarah-dan-

perkembangannya.htm\#.VChyyhYgnIU , diakses Senin, 29 September 2014 jam 3.45 WIB

http://repository.unand.ac.id/17447/1/skripsi_siti.pdf, diakses Selasa 14 Oktober 2014 jam 11.43 WIB

http://www.germanlawjournal.com/pdfs/Vol05/PDF Vol 05 585-

602_special_issue_Dumitriu.pdf, diakses Senin, 29 September 2014 jam 4.16 WIB 